\title{
Eight-Point Scheme Proposal for Translating the Qur'anic Text
}

\author{
Ali Al-Halawani \\ International Islamic University Malaysia, Kuala Lumpur, Malaysia
}

\begin{abstract}
The purpose of this paper is to examine the issue of translating the Qur'anic text into foreign languages. In so doing, the paper considers the unique features and characteristics of the language of the Qur'an and the special difficulties encountered by translators, from many different backgrounds, of the divine text. Different types of translation in relation to the Qur'an - literal, non-literal, and interpretive - are briefly discussed. Based on this discussion, this paper proposes an eight-point scheme to best translate the meaning of the different Qur'anic terms and/or expressions. This scheme can be applied either by an individual translator or a body of translators alike. This paper shows that the language of the Qur'an poses considerable obstacles to the translators. Thus, the best mode of translation in relation to the Qur'an is the interpretive one. It also calls upon researchers and translators to examine the proposed eight-point scheme for validity, usefulness, and further development.
\end{abstract}

Keywords: eight-point scheme, interpretive translation, translating the untranslatable, translation of the Qur'an

\section{Introduction}

Believed by Muslims as their sacred book, the Qur'an was sent down by Allah to Prophet Muhammad (PBUH) more than 1,400 years ago to be conveyed to all humanity. Interest in the translation of the Qur'an grew with Islam itself, as Muslims needed to transfer the meaning of many Qur'anic texts to non-Arabic speaking reverts to help them perform the prescribed acts of worship and to understand the faith. The West took interest in the Qur'an even before Alexander Ross had finished his translation in 1649, which was followed by George Seal in 1734, J. M. Rodwell in 1861, M. M. Pickthall in 1930, and A. Y. Ali in 1934. Many others also translated the Qur'an, including Westerners (Muslims and non-Muslims), Arabs, Iranians, and Turks. Translators were, and still are, faced with numerous challenges upon undertaking the translation of the Qur'anic text. There is a real need for finding an accurate and precise method for rendering the terms/concepts of the Qur'an into foreign languages.

\section{Study Objectives}

This study was based on the following three research questions:

1. Is the Qur'an untranslatable?

2. What is the best mode of translation in reference to the Qur'an?

3. Is there any methodical way to reduce the translator's personal interpretation of the Qur'anic text, and hence, his/her impact on the translation product?

Ali Al-Halawani, Ph.D., assistant professor, Kulliyyah of Languages and Management, International Islamic University Malaysia. 


\section{Literature Review}

Though there are several studies on the translation of the Qur'an (Versteegh, 1991; Abdul-Raof, 2001, 2005; Al-Shabab, 2008, 2012; Mustafa, 2011), no one - to the knowledge of the present author - has proposed an integrated methodical scheme for the translation of terms/concepts of the Qur'an in a way that may reduce the translator's personal interpretations, and hence, impact on the translation product. Basically, the translation of the Qur'an should be accurate, precise, and conform perfectly with sound faith as far as Islam is concerned. To do this, the translator should fully and precisely understand the source language (ST), and then transfer it into the target language (TL) faithfully, accurately, and precisely, without violating any of the meanings or features of the ST. To quote Dickins, Hervey, and Higgins (2002):

The subject matter of religious texts implies the existence of a spiritual world that is not fictive, but has its own external realities and truths. The author is understood not to be free to create a world that animates the subject matter, but to be merely instrumental in exploring it. (p. 178)

Many are those who attempted to solve the problems involved in the translation of religious texts in general and the Qur'anic text in particular into foreign languages. It goes without saying that a plethora of literature has been written on the issue, and many scholars suggested different models for translating the divine text. Moreover, some scholars claimed the Qur'an to be untranslatable, while others believed that it is necessary to render the meaning of the Qur'anic text into other languages to make it accessible to the Muslims who do not know Arabic, who make up around $80 \%$ of the 1,500,000,000 Muslims in the world, for them in order to appreciate the meanings of their sacred book. Taking this into consideration, the researcher prefers to call any translation work where the Qur'anic text is involved as "a translation of the meaning of the Qur'an" or "an interpretation of the Qur'an."

Khaleel (2005) assessed several translations of the Qur'an and categorized them as follows:

1. Early translations, in which he mentioned those translations carried out by Christians who sought to debunk Islam and help to convert Muslims to the Christian faith, such as Alexander Ross.

2. Twentieth century classics, under which he mentioned The Holy Qur'an by Muhammad Ali, The Meaning of the Glorious Koran by Muhammad Marmaduke Pickthall, and The Koran Interpreted by Arthur Arberry.

3. Saudi-endorsed translations, which include The Holy Qur'an: Translation and Commentary by Abdullah Yusuf Ali, and The Noble Qur'an in the English Language by Muhammad Taqi al-Din al-Hilali and Muhammad Muhsin Khan.

4. Translations aimed at bucking the Saudi orthodoxy, which include The Message of the Qur'an by Muhammad Asad, Al-Qur'an: A Contemporary Translation by Ahmed Ali, and The Qur'an: The First American Version by Thomas B. Irving.

5. Sectarian translations, which include The Holy Qur'an by Syed V. Mir Ahmed Ali and The Noble Qur'an: A New Rendering of Its Meaning in English by Abdalhaqq Bewley and Aisha Bewley.

6. Falling short translations, which sought to improve upon past translations but they fell short; this includes An Interpretation of the Qur'an by Majid Fakhry and The Qur'an: A New Translation by M. A. S. Abdel-Haleem. However, this was a general assessment due to limitations of the study.

Kidwai (1978) highlighted the various famous translations of the Qur'an without giving any details on how these translations were made or the strategies adopted by their respective translators in rendering them into English. 
This can be concluded by stating that each and every translator of the Qur'an mentioned something, be it detailed or abridged, on his/her translation and what makes it different from the others in a way that go beyond the scope of this present study.

\section{Significance of the Study}

Although the translator has to be merely instrumental in translating the Qur'an, many translations have been produced by various translators from different religious, cultural, and scholarly backgrounds. A matter which lead to the coloring of these translations in one way or another. Not only did some of these translations fail to recognize the linguistic and cultural dimensions of the Qur'anic text, but they failed to comprehend the real essence of its terms and/or concepts; not to mention those dimensions related to the prevalent spirit of the sacred text.

For this reason, this paper proposes an eight-point scheme to help translators of the Qur'anic text understand these linguistic and cultural dimensions as well as the spirit of the sacred text in a systematic, methodical, and objective manner, which will hopefully reduce — but unfortunately not eradicate - the error rate; as to err is human. It is an attempt to set up a methodical scheme for understanding and then translating the Qur'anic terms and/or concepts in a way that may reduce the translator's interference and influence on the transferred meaning into the TL.

This paper proves the importance of relying on an interpretive translation of the Qur'an instead of a literal or a meaning-based one, as the purpose of the translation is not only to translate the meaning, but also to provide some glimpses of the rhetorical inimitability of the Qur'anic text. It also stresses the importance of founding a high-profile specialized committee, instead of a single translator. This committee should include experts from different fields to fulfill this interpretive translation of the Qur'an as translation of the Qur'an cannot be a "one-man show," regardless of the competence, skill, and loyalty that translator may have. This translation should also be reviewed and replaced by a new one, if necessary, every 10 years to cope with the fast-paced changes of time.

\section{Status of Arabic}

There are 467,000,000 speakers of Arabic worldwide (Noack \& Gamio, 2015), rendering Arabic as the largest member of the Semitic branch of the Afro-Asiatic language family to which it belongs. It is one of the official languages of the United Nations as well as other international organizations. It has been a written language since the 6th century A.C., and is the liturgical language of Islam.

Arabic, as a term, refers to several varieties of the language, all of which are employed in the Arab world. The Arabic-speaking world can best be described as being "diglossic," as Modern Standard Arabic (MSA) is spoken fluently in the area along with a colloquial variety of Arabic that differs from one region to another. Basically, there are three types of Arabic: Colloquial Arabic, Classical Arabic, and MSA. Furthermore, Al-Sulaiti (2004, p. 35) mentioned a fourth form of Arabic labeled "Educated Spoken Arabic" (ESA), or the hybrid form.

Arabs believe, according to Haeri (2003), that their language has been perpetuated and kept alive (only) because it is the language of the Qur'an. Similarly, Guillaume (1949) stated that Arabic "expresses relations with more conciseness than the Aryan languages" (pp. vi-vii). This is because of the "extraordinary flexibility" of its verbs and nouns. To him, "... Many variations of the fundamental verbal theme can be expressed by 
vowel changes and consonantal augments" without resorting to any supplementary verbs or pronouns as employed in English, for example. Al-Khalil ibn Ahmed emphasized this in his book al-'Ain (The Eye) as he said, "One should know that a two-letter [Arabic] word can render [in terms of derivation] two different words..., and a three-letter word can render six words..., and a four-letter word can render 24 words..., and a five-letter word can render 120 words" (Al-Makhzumi \& Al-Samiraei, 1988, p. 59).

\section{Status of the Qur'an}

The Qur'an, according to Lane (1980, p. 2504), is said to be originally an inf. n.; qara', as in qara't-u al-shaiy'-a (meaning: "I collected the thing together"), or as in qara't-u al-kitab-a (meaning: "I read or recited, the book or scripture"); and it was then conventionally applied to signify "The Book of God" that was revealed to Prophet Muhammad.

Denffer (2009) identified it as "The Word of God (Allah), sent down upon the last Prophet, Mohammed, through the Angel Gabriel in its precise meaning and precise wording” (p. 17). Muslims believe that the Qur'an was then transmitted to us through numerous persons, both verbally and in writing, and that "It is inimitable and unique, protected by Allah from any corruption."

Moreover, the Qur'an was revealed in the most refined and eloquent of all languages, namely, Arabic. According to IbnFaris, Arabic is believed to be "the most refined of all languages" as it expresses many meanings using very few words. In addition, it is the "most disciplined, organized, eloquent and clear" of all languages. He also stressed that "the language of the Arabs has been divinely-revealed" (IbnFaris, 1997).

Muslims believe that the Qur'an is Islam's eternal miracle whose inimitability is continually confirmed through scientific research. It is also their belief that it was revealed to Prophet Muhammad to bring all men out of the darkness of disbelief and polytheism into the light of faith and monotheism.

Al-Nawawi (1987) said in relation to the Qur'an that any precise objective survey on the number of printed works, research papers, and manuscripts related to the Qur'an, be it in the past or the present and which amount to tens of thousands, "will decisively prove that the Qur'an is the only book that ever received so much attention in terms of study, research and in-depth surveys" (p. 5).

Remarkably, Al-Nawawi wrote this nearly 760 years ago. In fact, authoring discourses about the Qur'an have never ceased, and this research at hand attests to this in a way that needs no further evidence.

\section{Distinct Features of the Qur'anic Language}

Purity of the Qur'anic text has already been acknowledged by many. Muir (1894) wrote, "There is probably in the world no other book which has remained 12 centuries with so pure a text." Similarly, purity of the Qur'an was stressed by Wherry (2006), who stated, "This text of the Quran is the purest of all the works of alike antiquity" (p. 349).

Dispelling any doubt as to the genuineness of the Qur'an, Lane et al. (2003, p. 3) stated that, "There is such an immense amount of merit in the Qur'an that there is no doubt at all as to its genuineness." He further said that we can now read the Qur'anic text "with full confidence that it has remained unchanged through nearly thirteen hundred years."

In addition, many Orientalists, none of whom is well-known for his sympathy with Islam and its Prophet, had to acknowledge the fact that the Qur'an is "the most widely read book in existence" (Potter, 1995, p. 18; Hitti, 1958, p. 426). 
The Qur'anic style has a number of unique features that are unshared by any other book ever known to man. Al-Baqillani (1954, pp. 33-47) and Al-Rafi'i (1997, pp. 188-208) cited some of the features that can be summarized as follows:

1. The Qur'an differs in form from the three modes of expression known to the Arabs at the time of its revelation, namely day-to-day speech, speech of soothsayers, and poetry.

2. Its entire text is free from any discrepancy, as all of its sections enjoy the same standard of rhetoric excellence. No section thereof is better than another. Apparently, this is beyond human capacity as Al-Rafi'i attributed the differences in the styles used by humans to the psychological changes they constantly endure. Were the Qur'an man-made, its style would inevitably suffer from similar human discrepancies.

3. Unprecedentedly, it originated the terms which express Islamic and shari'ah-based meanings and concepts.

Though "deliberate repetition" was known to the Arabs as a subtle linguistic phenomenon, its occurrence in the Qur'an confirmed their inability to imitate or produce anything similar to it. Even though a particular meaning is expressed in two or three distinct forms therein.

Unlike any terms comprising any other speech, Qur'anic terms are marked by eloquence and splendor. Generally speaking, if a word were to be replaced in a text by another in the same language, the text would lose an aspect of its originality and eloquence, whatever the similarity between both words may be, as deemed by Al-Lawindi (2001, p. 22). This is true of any language in general, so how much more for the language of the Qur'an which is inimitable per se? "In its capacity as the Book of Allah," according to Ibn Attiyah, "If a word was taken out (from its text) and then an exhaustive search was conducted to find a better one to replace it, none would ever be found" (Al-Suyuti, 2004, p. 308; Musallam, 1999, pp. 134-135). Then, what would be the case if the original word was substituted for another from a different language?

Regarding the uniqueness of the Qur'anic text, Hussein (1948, p. 25) stated, "Linguists have failed to classify the style of the Qur'an; should it be considered prose or poetry?" According to him, they were bewildered in their attempts to understand its structures, and finally they considered it "a unique style different from prose and poetry." This is because it is characterized by features uncommon to all other styles. Some of these features are related to the endings of the ayahs (verses) and others to its unique musical rhythm, although it is not poetry, because "it does not fall under the [16] known categories of [Arabic] poetry."

Ascertaining the uniqueness of the Qur'an and the fact that it is incomparable to any similar speech, Al-Jahiz advocated that different names were given to it and to all its different components to those used in Arabic poetry in a way that proves the dissimilarity between the Qur'an and poetry, even with regard to naming its different components (Al-Suyuti, 2004, p. 178).

\section{Translating the Untranslatable}

Muslims believe that the Qur'an can only be read in the language in which it was revealed, namely Arabic. Anything else is just a translation of its meaning, and not the divine words of Allah. The significance of translating the meaning of the Qur'an emanates from the importance of the Qur'an itself, as it ranks first among the two main sources of the Muslim faith. Hence, it is no wonder that one sees a huge number of essays, books, and critical studies addressing the various translations that have been contributed by a large number of translators.

The Qur'anic text, to some scholars, such as Pickthall (1930), is untranslatable; to put it in his own words, "The Koran cannot be translated." That is his and the "old-fashioned Sheikhs"” belief, as he said. He further 
explained that his book was rendered almost literarily, and that he exerted himself to choose the most fitting language. However, "The result is not the Glorious Koran, that inimitable symphony; the very sounds of which move men to tears and ecstasy."

In his preface to the second edition of his translation of the meaning of the Qur'an, Ghali $(1998, \mathrm{p} . \mathrm{i})$ stated, "The Qur'an is untranslatable." He attributed the untranslatability of the Qur'an to the fact that "no human medium can reproduce the dignity and divine glory of the Arabic revelation." However, he admitted that each translation has its "distinctive value."

Arberry (2008) argued:

The Koran undeniably abounds in fine writing. It has its own extremely individual qualities; the language is highly idiomatic, yet for the most part delusively simple; and the rhythms and rhymes are inseparable features of its impressive eloquence which are indeed inimitable. (p. 28)

He further argued that the Qur'an "is neither prose nor poetry, but a unique fusion of both" (Arberry, 1998, p. $x)$. It is his belief that the rhetoric and rhythm of the Qur'an are so distinctive, powerful, and emotive that any translation is just a poor copy of the glorious original.

Tibawi (1962, pp. 17-28) strictly opposed any attempt to translate the Qur'an into any other language. He argued that "Arabic is abundant in metaphors, and no language could rival it in this sense." He stated that it "is unanimous; [all scholars agree] that it is virtually impossible to translate Arabic into any language, still less to translate the Arabic of the Qur'an" (pp. 17-28). In the same vein, in his book Al-Hayawan, Al-Jahiz (1965, pp. 74-79) maintained that it is impossible to translate Arabic poetry into any language, and that it is better not to attempt to translate any material dealing with religion and the Qur'an.

Abdul-Raof (2001) used "shifting" or reference switching to illustrate the fact that the Qur'anic discourse is characterized by various syntactic, semantic, rhetorical, and cultural features that are distinct from other types of Arabic discourse. To him, these features are untranslatable, and hence, he stresses the untranslatability of the Qur'an.

Similarly, Bultemeier (as cited in Al-Jabari, 2008, p. 20) argued that the translation of the Qur'an into any language is "impossible" for a number of reasons. Firstly, the translation must maintain the same effect on the reader of the TL as the original text of the Qur'an, but the Qur'anic verses loses the same symphonic effect if translated into any other language. Secondly, to him, the Qur'an contains Syriac and Aramaic vocabulary, a matter which is unusual to Arabic. This increases the complexity of the translation process since the meaning of certain phrases is not clear, and different interpretations are possible (as cited in Al-Jabari, 2008, p. 20).

Arbuthnot (1985) stated, "From the literary point of view, the Koran is regarded as a specimen of the purest Arabic, written in half poetry and half prose" (p. 245). According to him, grammarians have adapted their rules to agree with certain phrases and expressions used therein, and though many have attempted to produce something equal to it, "As far elegant writing is concerned, none have, as yet, succeeded."

It is clear that the inimitable rhetoric of the Qur'an has been unanimously declared impossible to translate. Notwithstanding, the possibility of transferring its meaning into other languages is still maintained. Thereupon, the objective of the translation process should only be for missionary ( $\left.d a^{\prime} w a h\right)$ purposes.

Qur'an translation history is quite long and the list of translations contributed so far is endless, as new translations constantly appear. In his attempt to numerate these translations, Al-Lawindi (2001) concluded, "It is said that the translations of the Qur'an into the different world languages amount to more than 700 
translations up till now" (p. 19). However, surveying and/or assessing these translations is not the aim of this initial paper.

\section{Meaning of “Translation” in Reference to the Qur'an}

Three types of translation can be distinguished when discussing the case of the Qur'an: literal, meaning-based (i.e., non-literal), and interpretive translations.

\section{Literal Translation}

This is word-for-word translation. In Al-Qattan's (1990) words, "It is to transfer [a set of] lexical items from one language to their matches in another language, so that both the style [of the text] and the order [of the lexical items] become identical" (p. 324). However, this proves to be almost impossible between any two languages. As far as the Islamic shari'ah is concerned, this type of translation is neither possible nor legal, except for the verses which can be literally translated (Zaqzuq, 2006, pp. 863-866).

Literal translation renders only the denotative meaning of the lexical item as it is listed in the dictionary. Certainly, the connotative meaning of an Arabic word differs from that of an English word, even if their denotative meanings are almost the same. Consequently, the rendered meaning fails to transfer not only the genuine meaning, but also the general context of the ST. Attesting to this, Dickins et al. (2002) stated, "Meanings are not found exclusively in the words listed individually in the dictionary" (p. 97).

Hence, literal translation neglects the subtle meanings with which the Qur'anic text is replete. Even with a cursory investigation, it becomes clear that this type of translation is unable to attend to the inimitable style and structure of the Qur'an, which cannot be maintained even in Arabic with other non-Qur'anic terms.

In other words, the difficulties ensuing from the literal translation of the Qur'an into other languages stem from the Qur'an's inimitable wording. A matter which renders its translation impossible unless it is restricted to its basic meaning or the personal interpretation of the translator. In addition, the Qur'an's magnificent rhyme, eloquence, and style that deeply impress man's soul are lost in the literal translation.

\section{Meaning-Based Translation}

This refers to rendering "the meaning of a text in another language by neither abiding by the order of the lexical items in the original text, nor by its structure," as explained by Al-Qattan (1990, p. 324).

All eloquent Arabic texts, topped by the Qur'an, have basic and secondary meanings. The basic meaning stands for the conclusive type of meanings or messages which anyone can understand once he understands the meaning of the word in use. There is a high possibility that such meanings can be conveyed into any other language. However, and particularly with the Qur'an, there are also secondary or implicit meanings which are almost impossible to translate into another language, especially if one takes into consideration the eloquence of the text. This type of meaning is what testifies to the inimitability of the Qur'an. Arguing for this, Al-Zamakhshari (1998) stated, "Indeed, there are in the Arabic language in general and in the Qur'an in particular subtle implicit meanings that cannot be expressed by any other language" (p. 476).

Al-Shatibi (2003, pp. 56-57) dichotomized the meanings portrayed in all languages, including Arabic. The first include "the general terms and expressions which denote broad meanings and constitute the basic or abstract meaning of these terms and expressions," while the second include "the specific terms denoting secondary, implicit meanings." According to him, it is the first type that is common among all languages and which enables humans to communicate. Consequently, translation at this level from Arabic into other languages is "possible." 
However, this overgeneralization concerning the validity of translation based on only the basic meaning is opposed by Al-Qattan (1990, p. 326), who stated that some scholars see translation as permissible only in case of necessity, such as the need to convey the message of tawhid (Islamic monotheism) and/or teach the ibadat (acts of worship), and nothing more. He concluded, "As for those who crave to obtain more knowledge, they should be encouraged to learn Arabic."

Remarkably, most translations of the Qur'an into the different world languages can safely be attributed to this type, i.e., meaning-based translation. There are a few exceptions to this as some contributors felt the deficiencies of this type. To make up for these deficiencies, they added illustrative remarks and basic comments which they considered necessary, in the footnotes. Yusuf Ali's translation suffices as an example of this. However, almost all translations contain interpretations of some expressions and terms that fail to transfer their denotative as well as connotative meanings.

\section{Interpretive Translation}

This is when a translator finds it impossible to transfer the entire meaning of the Qur'anic terms and expressions. Hence, he/she develops a personal understanding of the text at hand, and then sets out to render this understanding into the TL (Al-Qattan, 1990, pp. 327-328).

In this sense, interpretive translation is different from the meaning-based one, though they might be confused with each other. The latter gives the false impression that the translator has grasped all the meanings of the Qur'an and was successful in transferring them all into the TL. It is as if one says, "This is exactly what the ayah means!" Whereas the translator, in the interpretive type, attempts to reproduce the text as per his personal understanding of it; as if he says, "This is what I think the ayah means!"

Stressing the validity of this method which is deemed by Al-Lawindi (2001, p. 40) as a "must" in light of the difficulty of both the literal and meaning-based translations, he argued that if Muslims neglect the issue of translating the Qur'an, they would be without any "reference or support" in many regions of the world. They would end up finding an Arabic Qur'an in their hands which they truly "respect," but of which they "basically comprehend nothing!" To him, the natural consequence of this is that the meaning of the Qur'an will remain "incomprehensible to many nations," a matter which is both unfair and contradictory to the universality of Islam.

To Al-Shabab (1998), translation is merely an "an interpretative (hermeneutic) behavior." This interpretive nature of translation is destined to give rise to "differences" in translation.

O’Donnell (2004) also stated, "Every translation is an interpretation, and therefore, even when making a quick initial translation, the exegete is forced to make interpretative decisions" (p. 165). This conforms with Levi (1967), who advocated translation "as a decision process." It is "a dynamic process of comprehension and re-expression of ideas," as deemed by Salama-Carr (2011, p. 146).

\section{Significance of an Interpretive Translation}

Translating the terms and expressions comprising the Qur'an is, by definition, challenging. It becomes nearly impossible if one wishes to simultaneously provide equivalents for all the meanings denoted by and associated with the term in its textual context. In other words, it would be impossible for any translator, regardless of his/her competence and skill, to render both explicit and implicit meanings of the Qur'anic terms and expressions. Hence, the need arises for a methodical procedure that may enable the translator(s) to fully understand the meaning of these terms without causing any loss in translation. This is what this paper stands for 
as it proposes an eight-point scheme for the translation of the Qur'an in a way that may reduce the translator's personal influence or presumptions in relation to what is denoted and/or connoted by the different elements of the sacred text.

The more the translators understand the text, the more they become aware of their own incompetence and the insufficiency of any other language to express the same sort of inimitability involved. Ayoub (1997, p. xi) noted, "Because the Qur'an stresses its Arabic nature, Muslim scholars believe that any translation cannot be more than an approximate interpretation intended only as a tool for the study and understanding of the original Arabic."

Moreover, Bewley, A., and Bewley, A. (2005, p. v) argued that Allah "chose pure, Classical Arabic as the linguistic vehicle" for His Book because of its "unique capacity to retain and convey a great depth of meaning in a multi-faceted way" which goes beyond "the scope of any other language."

In other words, the Arabic terms and/or concepts used in the Qur'an represent a wealth of ideas with various subtle shades of meaning that cannot be expressed in full with a single word equivalent in any language. To illustrate, two Arabic terms from Al-Kahf (Chapter No. 18), namely ista'-u and istata'- $u$, can be cited. Both terms are translated interchangeably as "could" or "was able to" by Sale, Muhammad Ali, Pickthall, Rodwell, and others, all of whom overlooked the delicate difference in meaning between the two terms. As the former is only used for relatively easy actions, such as climbing a wall, while the latter is used for harder tasks, such as making a hole in a solid wall. This is based on the Arabic rhetorical rule that the more letters a word has, the more or stronger meanings it denotes.

Another example can be the set of terms mata and ayyan- $a$, as the subtle difference between both have hardly been discerned in any translation the researcher has ever read. Though both stand for the interrogative "when," the term "ayyan-a" implies a denial that the event in question will ever take place.

Earlier, it was mentioned that a literal translation is neither possible nor acceptable. It also became clear that translating the implicit meanings of the Qur'an, which mark its inimitability goes beyond human capacity. The basic meanings of the Qur'an can be rendered into other languages. However, this also requires maximum caution so as not to charge these meanings with unintended associations. Consequently, translators can only translate their own personal interpretation of the Qur'an, or translate an authoritative interpretation prepared by a high-profile specialized committee. The author accepts the second option as it may reduce the vulnerability to err incurred by a single translator's personal understanding.

In this connection, it must be stressed that the inimitability of the Qur'an does not prevent it from being translated, as there are various aspects of this inimitability. Some are "Arabic-specific," as they are related to the language, style, and rhetoric of the Qur'an, while others are "general". These general aspects can be realized by discerning people of different races (Al-Lawindi, 2001, pp. 29-30). These general aspects refer to: (a) the unseen; (b) narrations of the past; and (c) the legislations regulating various activities in life, be they private or public. Hence, if the translation fails to convey the "specific" aspect related to the style and rhetoric of the Qur'an, it will not in any way affect the other aspects related to historic events and the like. It should also be borne in mind that the intended translation is of the meaning of the Qur'an, not the Qur'an itself, as was stated earlier.

Irving (1985) stated, "The Qur'an could be considered untranslatable, because each time one returns to the Arabic text, he finds new meanings and fresh ways of interpreting it" (p. 27). Concerning the meaning, Irving (1985, p. 30) warned that any translation is affected by the translator's thoughts. This is to say that God's Word could be manipulated in one way or another. To circumvent this, the following methodical procedure is proposed. 


\section{The Proposed Eight-Point Scheme}

This scheme is designed for individual and group translators alike to adopt upon seeking to render the Qur'anic text into any TL. It is intended to help translators produce more precise and accurate renditions of the divine text. This scheme is based on a number of rules that were first introduced by Al-Maidani (2004, pp. 317-428) in the context of teaching Muslims how to contemplate the Qur'anic text to maximize their understanding thereof. The author believes these rules, with necessary changes, can be applied by translators in their pursuit of a precise translation of the Qur'an into other languages. The modified rules read:

1. To consult Classical Arabic reference dictionaries on the various meanings and uses of the Qur'anic term and/or expression at hand;

2. To define literal vs. figurative uses of the Qur'anic term and/or expression as it was used by Arabs during the time the Qur'an was being revealed;

3. To consider reported explanations from Prophet Muhammad and take them as a frame for understanding Qur'anic terms and/or expressions;

4. To study significant contributions of key commentators on the Qur'an; this may give more enlightenment on the intended meaning;

5. To contemplate all occurrences of the term and/or expression in the Qur'anic text; this may reveal the basic denotations as well as connotations of the term in the text at hand; whether it revolves around the lexical or the shari'ah-based meaning, the literal or the figurative meaning, or both but in different contexts;

6. To recognize all relevant Islamic concepts side by side with other Qur'anic concepts;

7. To look thoroughly into the overall meaning of the text at hand while observing its context within the surah;

8. To determine the exact meaning of the term and/or expression at hand based on the aforementioned procedures; then to select the best possible equivalent thereof from the TL.

This TL equivalent should be able to communicate the "obtained" exact meaning of the Qur'anic term and/or expression without any trace of ambiguity or imprecision. There may even be an exact TL equivalent for the Arabic term and/or expression, so translators may think that they will not encounter any problems in transferring the meaning of such terms and/or expressions into the TL. However, they should be aware that the case is not that easy as far as the Qur'an is concerned, as:

1. A Qur'anic term may have a TL equivalent for one of its occurrences in the divine text, but require another equivalent (or more precisely, equivalents) for other occurrences, such as the term ummah, which can be rendered into English as "anation," "a community," "a group of people," "a religion," "a period," "a time," "a guide," etc., according to the context at hand.

2. The TL may have two variant equivalents or synonyms for a single Qur'anic term and/or expression. Hence, the translator should choose the most suitable one in light of the Qur'anic usage in the context at hand.

3. The TL may not have a perfect equivalent for the Qur'anic term and/or expression. Hence, the translator should use the closest equivalent and support it with sufficient explanation that may appear in either a footnote or a glossary.

To transfer the meaning of a SL text into TL, one should perfectly understand the meaning of the terms and/or expressions comprising the ST. Thus, understanding the Qur'anic terms and expressions is of crucial importance to the success of the translation process per se. Therefore, consulting Classical Arabic 
dictionaries/lexicons is of major significance, particularly when there seems to be a contradiction between a scientific fact and the understanding of some commentators of particular ayahs in the Qur'an. Let us consider

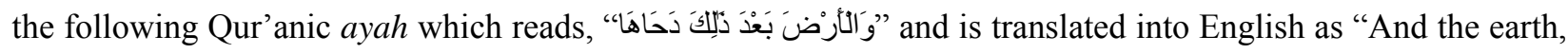
after this, He alone spread" (al-Nazi’at 79: 30; Trans. by Hammad, 2009).

Eight other different translations of the Qur'an were consulted. It was found that the following English equivalents are used to denote the meaning of the term at hand: "spread the earth," "cast it," "spread the earth," "made the earth egg-shaped," "spread out the earth," "expanded it," "spread forth," and "extended" (to a wide expanse). ${ }^{1}$ Clearly, all these equivalents revolve around two basic concepts, "expansion" and "making the earth egg-shaped." Nevertheless, thorough examination of Classical Arabic lexicons may provide other possible interpretations which may be seen as more relevant to modern scientific discoveries.

Different classical commentators relied on the same concepts to denote the Arabic term daha. However, consulting Lane's lexicon, an authentic rendition of Lisan al-Arab by Ibn Manzur, proved the existence of other meanings and interpretations of the term that should have been considered upon explaining the meaning of the ayah. Indeed, expansion and spreading — adopted by almost all commentators - are among the meanings of the term. This can be justified as it represents the basic idea many people had regarding the flatness and relative levelness of the earth. However, other meanings, which are more relevant to recent astronomical discoveries, can be found therein. Hence, adding a significant dimension to the Qur'an's scientific inimitability.

According to Lane (1980, p. 857), daha stands for the following meanings "He threw or cast...". And, “بدحو الحجارة", yad-hu al-hijarat'a, meaning...

He threw, or cast, and impelled, propelled, or removed a stone from its place with his hand. One also says to him who is playing with walnuts, “بعد المدى وادحه", ab'id-ilmada wad-hi-hi, meaning "Make thou the distance far, and throw it". And of rain, one says, “دحا الحصى عن وجه الأرض", dahaal-hasa'anwajh-ilard-i, meaning "It drove the pebbles from the surface of the earth; or removed them". (p. 857)

He also said:

"بدحو الحجارة", yad-hual-hijarat-a, meaning [to throw stones]. "لمداحي", al-madah-i, refers to stones, which are the shape of a small round cake called a qursah "قرصنة", and are thrown into a hole. This hole was dug to be the same size as these stones with the top edge of the hole (at the level of the ground) being slightly wider; if the stone falls therein, the person wins; but if not, he is overcome. You say of him "يدحو", yad-h-u, when he throws the stones over the ground to the hole, and the hole is called "أدحية", ad-hiyah. (p. 857)

These small stones roll or rotate around themselves while moving over the ground after being thrown.

According to these Arabic uses of the term, daha implies two more concepts: (a) An act of throwing or pushing by the person involved; and (b) One of two movements witnessed by the thrown object, either to follow a specific course, or to rotate around its own axis. Considering the earth's movement, it resembles a huge rock "thrown" in space with two movements: rotating around the sun and rotating around its own axis.

Accordingly, it is probable that the meaning of the ayah encompasses these kinds of movements side by side with the meaning of expansion and extension highlighted by all previous commentators.

As was mentioned earlier, this scheme can be applied by individual translators and/or high-profile specialized committees undertaking the task of translating the Qur'anic text. Preparation of such a translation is

${ }^{1}$ The translations consulted were Khan, Maulana, Pickthall, Rashad, Sarwar, Shakir, Sher Ali, and Yusuf Ali, respectively. 
not easy. It requires the joint efforts of a number of specialists in the fields of linguistics, translation studies, Islamic shari'ah, Qur'anic studies, and modes of the Qur'an's recitation, along with experts in natural sciences, such as astronomy, biology, geology, medicine, etc.. Most importantly, it should involve professional translators with a minimum experience of 20 years in the field of translating religious and Islamic texts. This is indispensable, for perfection cannot be achieved with poor tools. This committee should work under the auspices of either Al-Azhar (Egypt), King Fahd Quran Printing Complex (Saudi Arabia), the International Union for Muslim Scholars (IUMS), or a similar international body. Following the preparation of the interpretation of the Qur'anic text by these specialists, the translation process commences. Only one or two translators are needed to actually translate the text after applying the aforementioned scheme; the rest of the translation team should then come aboard to meticulously read, review, verify, and demand necessary changes or modifications in a way that improves the work at hand. Eventually, a precise and authentic image of the Qur'an may be reflected.

Principally, no single translation suffices any great work. "Every great book demands to be translated once in a century to suit the change in standards and taste of the new generations, which differ radically from those of the past" (Cohen, 1962, p. 215). The same view is held by Lefevere (1977), who stated, "Different ages need different adjustments and translations" (p. xi). Though tempted to agree with both scholars on this concept, the researcher objects to the duration required to produce a new rendition of such a great book as the Qur'an. A span of 10 years is sufficient for producing a new rendition of the meaning of the Qur'an to cope with the ever rapid progress rate witnessed by our fast-moving world.

\section{Conclusion and Recommendations}

Of the persistent problems encountered by translators of the Qur'an-individuals and committees alike - is the translation of Qur'anic terms and/or expressions. Hence, the importance of this paper as it provides a scheme for rendering these into any foreign language in a methodical manner. It can also be used in the field of tafsir (commentary on the Qur'an), as it may furnish commentators with new insight on the intended meanings of the divine text. The study attempted to answer three main questions: 1. Is the Qur'an untranslatable? 2. What is the best mode of translation in reference to the Qur'an? and 3. Is there any methodical way to reduce the translator's personal interpretation of the Qur'anic text, and hence, his/her impact on the translation product? These questions can be answered respectively as follows: 1. The Qur'an's meanings can be translated into other languages; 2. The interpretive mode of translation is the best among all other translations modes, such as the literal and the meaning-based translation; and 3. There was no any methodical way to reduce the translator's personal interpretation of the Qur'anic text and that is why the study proposes this eight-point scheme for translating the Qur'anic terms/concepts.

However, the proposed interpretive translation here should conform to the rules of Arabic as well as the established shari'ah rules and main Islamic concepts. To do this, the aim of the translation should be to transfer all possible linguistic meanings, associations, and also social, cultural, and civilizational dimensions of the Qur'anic text. It also goes without saying that if the translator is capable of transferring the rhythmic and rhetorical impact of the original into the TL, that would be highly appreciated.

Translators and academics are kindly asked to examine this proposed eight-point scheme to see whether or not it can be of any use, as far as the translation of the Qur'anic text is concerned.

Finally, the field remains open for future attempts to reflect the true meaning of the Qur'an, because this 
mandates not only translation but also a better understanding of its text and context alike. Amazingly, the quest for a "perfect" rendition of the divine text seems endless.

\section{References}

Abdul-Raof, H. (2001). Quran translation: Discourse, texture and exegesis. Leeds, U.K.: Curzon Press.

Abdul-Raof, H. (2005). Cultural aspects in Qur'an translation. In L. Lynne (Ed.), Translation and religion, topics in translation. Multilingual Matters LTD.

Al-Baqillani, A. B. M. (1954). I'jaz al-Qur'an (Inimitability of the Qur'an). Cairo: Dar Al-Ma'arif.

Ali, A. Y. (1946). The holy Qur'an: Text, translation and commentary. Jeddah, Saudi Arabia: Islamic Foundation Center.

Al-Jabari, R. (2008). Reasons for the possible incomprehensibility of some verses of three translations of the meaning of the holy Quran into English (Ph.D. dissertation, School of Languages, University of Salford, Salford, UK).

Al-Jahiz, A. U. A. (1965). Al-Hayawan (The animal). Cairo: Al-Halabi Press.

Al-Lawindi, S. (2001). Ishkaliyat Tarjamat Ma'ani al-Qur'an al-Karim (Problem of translating meanings of the noble Qur'an). Cairo: Markaz al-Hadarah al-'Arabiyyah.

Al-Maidani, A. R. H. (2004). Qawa'id al-Tadabbur al-Amthal li Kitab Allah (Rules for the most appropriate reflection on the book of Allah). Damascus: Dar al-Qalam.

Al-Makhzumi, M., \& Al-Samiraei, I. (Eds.). (1988). Al-'Ain (The eye). Lebanon, Beirut: Al-A'lami Foundation for Printing.

Al-Nawawi, S. A. (1987). Al-Tibyan fi Adaab Hamalat al-Qur'an (The clarification on the etiquettes of memorizers of the Qur'an). Beirut: Dar Al-Nafa'is.

Al-Qattan, M. K. (1990). Mabahith fi'Ulum al-Qur'an (Studies on the sciences of the Qur'an).Cairo: Wahbah Publishing House.

Al-Qur'an Al-Karim (The Glorious Qur'an). (2009). Ministry of Endowments and Islamic Affairs, Qatar. Turkey, Istanbul: Mas Printing House.

Al-Rafi'i, M. S. (1997). I'jaz al-Qur'an wal-Balaghah al-Nabawiyyah (Inimitability of the Qur'an and prophetic eloquence). Cairo: Al-Tawfiqiyyah Bookshop.

Al-Shabab, O. S. (1998). Translating with difference: Theory and practice. Damascus, Syria: DEBS.

Al-Shabab, O. S. (2008). Linguistic and cultural translation in the translations of the holy Quran into European languages. Scientific Journal of King Faisal University, 9(2).

Al-Shabab, O. S. (2012). Textual source and assertion: Sale's translation of the holy Quran. Journal of King Saud University-Languages and Translation, 24(1)1-21.

Al-Shatibi, A. I. (2003). Al-Muwafaqat fi Usul al-Shari'ah (Agreements on the fundamentals of Islamic law). Cairo: Al-Tawfiqiyyah Bookshop.

Al-Sulaiti, L. (2004). Designing and developing a corpus of contemporary Arabic (Unpublished M.A. thesis, School of Computing, Leeds University, UK).

Al-Suyuti, A. R. J. A. (2004). Al-Itqan fi'Ulum al-Qur'an (Perfection in the sciences of the Qur'an). Cairo: Dar Al-Hadath.

Al-Zamakhshari, A. Q. (1998). Al-Kashshaf (The explorer). Saudi Arabia: Obeikan Publishers.

Arberry, A. J. (1998). The Koran interpreted: A translation. London, U.K.: Oxford University Press.

Arberry, A. J. (2008). The holy Koran: An introduction with selections. New York, N.Y.: Routledge/Taylor \& Francis Group.

Arbuthnot, F. F. (1985). The construction of the Bible and the Koran. London, U.K.: Watts.

Ayoub, M. (1997). The awesome news. Hiawatha, Iowa: Cedar Graphics.

Bewley, A., \& Bewley, A. (2005). The noble Qur'an: A new rendering of its meanings in English. Norwich: Bookwork.

Cohen, J. M. (1962). English translators and translations. London, U.K.: Longmans, Green.

Denffer, A. V. (2009). Ulum al-Quran: An introduction to the sciences of the Quran. Leicester, U.K.: The Islamic Foundation.

Dickins, J., Hervey, S. G. J., \& Higgins, I. (2002). Thinking Arabic translation, a course in translation method: Arabic to English. Abingdon, U.K.: Routledge.

Ghali, M. M. (1998). Towards understanding the ever-glorious Qur'an. Cairo: Publishing House for Universities.

Guillaume, A. (1949). The legacy of Islam. Oxford, U.K.: Oxford University Press.

Haeri, N. (2003). Sacred language, ordinary people: Dilemmas of culture and politics in Egypt. New York, N.Y.: Palgrave Macmillan.

Hammad, A. Z. (2009). The gracious Qur'an. USA: Lucent Interpretations, LLC..

Hitti, P. K. (1958). History of the Arabs. New York, N.Y.: Macmillan. 
Hussein, T. (1948). Hadith al-Shi'rwal-Nathr (Discussion on poetry and prose). Cairo: Dar Al-Ma'arif.

IbnFaris, A. (1997). Al-Sahibi fi Fiqh al-Lughah al-'Arabiyyah (Al-Sahibi on Arabic philology). Beirut, Lebanon: Dar al-Kutub al-'Ilmiyyah.

Irving, T. B. (1985). The Qur'an: The first American version. Battleboro, V. T.: Amana Books.

Khaleel, M. (2005). Assessing English translations of the Qur'an. Middle East Quarterly, 12(2), 58-71.

Kidwai, A. R. (1978). A survey of English translations of the Qur'an. The Muslim World Book Review, 7(4).

Lane, E. W. (1980). An Arabic-English lexicon. Beirut, Lebanon: Libraire Du Liban.

Lane, E. W., \& Lane-Poole, S. (2003). Selections from the Kur-an. New Delhi, Chennai: Asian Educational Services.

Lefevere, A. (1977). Translating literature: The German tradition from Luther to Rosenzweig. Assen \& Amsterdam: Van Gorcum.

Levy, J. (1967). Translation as a decision process. In To honour Roman Jakobson: Essays on the occasion of his seventieth birthday (October 11, 1966, Vol. 2.). The Hague: Mouton.

Muir, W. (1894). Life of Mohamet (Vol. 1). London.

Musallam, M. (1999). Mabahith fi I'jaz al-Qur'an (Studies on the Inimitability of the Qur'an). Damascus: Dar Al-Qalam.

Mustafa, H. (2011). Quran. In M. Baker, \& G., Saldanha (Eds.), Routledge Encyclopaedia of translation studies (2nd ed.). London, U.K.: Routledge.

Noack, R., \& Gamio, L. (2015). The world's languages, in 7 maps and charts. Retrieved September 22, 2015, from http://www.washingtonpost.com/news/worldviews/wp/2015/04/23/the-worlds-languages-in-7-maps-and-charts/

O'Donnell, M. B. (2004). Translation and the exegetical process, using marks 5.1-10: "The binding of the strong man", as a test case. In S. E., Porter, \& R. S., Hess (Eds.), Translating the Bible: Problems and prospects. T \& T Clark International, A Continuum imprint.

Pickthall, M. M. W. (1930). The meaning of the glorious Qur'an. Hyderabad-Deccan: Government Central Press.

Potter, C. F. (1959). The faiths men live by. The World's Work (1913) Ltd., Kingswood, Surrey.

Stanley, E. P., \& Richard, S. H. (Eds.). (1999). Translating the Bible: Problems and prospects. London, U.K.: Bloomsbury T \& T Clark.

Tibawi, A. L. (1962). Is the translation of the Qur'an possible? Early Muslim opinions. The Muslim World, 52, 17-28.

Versteegh, K. (1991). Greek translations of the Quran in Christian polemics (Ninth Century A.D). Zeitschrift der Deutschen Morgenlandischen Gesellschaft, 141(1), 52-68.

Wherry, E. M. (2006). A comprehensive commentary on the Qur'an. Whitefish, M. T.: Kessinger Publishing, LLC..

Zaqzuq, M. H. (Ed.). (2006). Al-Mawsu'ah al-Qur'aniyyah al-Mutakhasisah (The specialized Qur'anic Encyclopaedia). Cairo: The Supreme Council of Islamic Affairs. 